\title{
MASJID WAKAF DAN TRANSFORMASI SOSIAL UMAT DI MASJID BESAR IMAM ULOMO SAMPUNG PONOROGO
}

\author{
Miftahul Huda \\ IAIN Ponorogo \\ Email:elhoeda@yahoo.co.id \\ Lukman Santoso \\ IAIN Ponorogo \\ Email: lukmansantoso4@gmail.com
}

\begin{abstract}
Great Mosque Imam Ulomo Sampung Ponorogo is a waqf mosque located in the countryside. Making the mosque as a partner devotion is ikhtiyar Masjid realize that far from urban areas and are in the corners to not only as a religious social center but also pursued into the mosque advanced and progressive socio-economic and even become an example for others in the interior of the mosque. Based on the above discussion, this article examines Waqf Masjid and Social Transformation of People in the Great Mosque of Imam Ulomo Sampung Ponorogo. The aim of this devotion as an Islamic community development efforts related to change management model endowments, from traditional to professional. Based on the study, it can be concluded: First, performing well through socialization and training paradigm of governance productive endowments. Second, institutional strengthening training nadzir endowments. This activity is very beneficial to the development and improvement of governance endowments productive in society, in particular institutional waqf mosque.
\end{abstract}

Keywords: endowments, mosques, transformation, Imam Ulomo

\begin{abstract}
Abstrak
Masjid Besar Imam Ulomo Sampung Ponorogo merupakan masjid wakaf yang berada di pelosok desa. Menjadikan masjid sebagai mitra pengabdian adalah ikhtiyar mewujudkan Masjid yang jauh dari perkotaan dan berada di pelosok untuk tidak hanya sebagai pusat sosial keagamaan tetapi juga diupayakan menjadi masjid yang maju dan progresif secara sosial-ekonomi bahkan menjadi contoh bagi masjid di pedalaman lainnya. Berpijak pada pemikiran di atas, artikel ini mengkaji tentang Masjid Wakaf dan Transformasi Sosial Umat di Masjid Besar Imam Ulomo Sampung Ponorogo. Pengabdian ini bertujuan sebagai upaya pembangunan masyarakat Islam terkait perubahan model pengelolaan wakaf, dari tradisional menjadi profesional. Berdasarkan kajian, dapat disimpulkan: Pertama, terlaksana dengan baik melalui kegiatan sosialisasi dan pelatihan paradigma tata kelola wakaf produktif. Kedua, pelatihan penguatan kelembagaan nadzir wakaf. Kegiatan ini sangat bermanfaat bagi pengembangan dan peningkatan tata kelola wakaf produktif di masyarakat, khususnya kelembagaan masjid wakaf.
\end{abstract}

Kata kunci: wakaf, masjid, transformasi, Imam Ulomo 


\section{A. Pendahuluan}

Pengabdian kepada masyarakat merupakan salah satu bentuk tridharma Perguruan Tinggi disamping pendidikan dan penelitian. Sejak awal gagasan pendirian perguruan tinggi adalah mengembangkan ilmu pengetahuan, mempersiapkan warga negara yang cerdas, berilmu, beriman, dan beramal untuk kemajuan bangsa, serta berkhidmat kepada masyarakat yang ada. Semangat keutuhan atau integrasi tridharma ini dimandatkan melalui Undang-undang No. 12 tahun 2012 Tentang Pendidikan Tinggi. ${ }^{1}$ Dalam UU ini pengabdian pada masyarakat diartikan sebagai kegiatan sivitas akademika yang memanfaatkan ilmu pengetahuan dan teknologi untuk memajukan kesejahteraan masyarakat dan mencerdaskan kehidupan bangsa.

Sampai saat ini, Tipologi Pengabdian Morton ditengarai ada tiga paradigma, yakni sebuah cara pandang dan model pengabdian kepada masyarakat. ${ }^{2}$ Paradigma ini merupakan kerangka umum pemikiran dan asumsi-asumsi yang mempengaruhi dan dipengaruhi oleh nilai-nilai dan perilaku masyarakat baik lokal atau global pada masanya. Paradigma pertama dikenal dengan nama Charity (Bhakti Sosial atau sedekah). Asumsi dari pemikiran ini adalah bahwa kampus merupakan pihak yang punya sumber daya pengetahuan dan teknologi dan karena itu berkewajiban untuk memberikannya atau mensedekahkannya kepada masyarakat yang dianggap sebagai pihak yang tidak punya dan selalu dalam keadaan membutuhkan uluran tangan perguruan tinggi.

Paradigma kedua adalah Project (Proyek). Asumsi-asumsi dasar dalam paradigma ini adalah bahwa pengabdian harus dilakukan dengan cara yang terorganisir. Oleh karena itu, model pengabdian ini diawali dengan kajian masalah yang dihadapi oleh masyarakat, menentukan solusi, merencanakan tindakan, dan menerapkan rencana untuk mencapai tujuan yang ditetapkan.

Paradigma ketiga biasa disebut dengan Social Change (Transformasi Sosial). Ini adalah paradigma yang meyakini nilai-nilai keadilan dan kearifan lokal. Pengabdian ini

${ }^{1}$ Lihat Undang-Undang Nomor 12 Tahun 2012 Tentang Pendidikan Tinggi

2 Robert G. Bringle, Julie A. Hatcher, and Rachel E. McIntosh, "Analyzing Morton"s Typology of Service Paradigms and Integrity," dalam Michigan Journal of Community Service Learning, MJCSL 13-1 10/11/06 (Fall 2006), 5-15 
menitikberatkan pada proses pengembangan hubungan intra-masyarakat sebagai satu kesatuan warga yang setara dan dengan pemangku kepentingan lainnya secara proporsional. Penciptakan lingkungan pembelajar secara kolektif dan kolaboratif adalah bentuk dari kegiatan pengabdian ini. Masyarakat dipandang sebagai satu unit komunitas yang mempunyai kuasa dan kendali atas asset, sumber daya, dan masalahnya sendiri. Dalam paradigma ini juga, masyarakat dianggap punya sesuatu, yaitu power (kekuatan dan kekuasaan) yang acapcali kurang atau tidak berkembang.

Dalam konteks teori diatas, dimensi wakaf merupakan salah satu aspek yang menarik untuk menjadi objek pengabdian. Perkembangan institusi wakaf saat ini tidak bisa dilepaskan dengan keberadaan Islam di tanah Nusantara. Wakaf, khususnya berupa wakaf tanah, sudah ada dan dilakukan semenjak lahirnya komunitas-komunitas muslim di beberapa daerah di Nusantara. Lembaga wakaf muncul bersamaan dengan lahirnya masyarakat muslim sebagai sebuah komunitas keagamaan yang pada umumnya memerlukan fasilitas-fasilitas peribadatan dan pendidikan untuk menjamin kelangsungannya. Fasilitas-fasilitas itu dapat terpenuhi dengan cara berwakaf, baik berupa wakaf tanah, bangunan, maupun aset wakaf lainnya.

Pijper melukiskan tentang praktik wakaf di Indonesia terhadap fenomena masjid sebagai sebuah harta wakaf. Harta wakaf tersebut tidak boleh diperjualbelikan, digadaikan, diwariskan, dan dihadiahkan. Hal ini disebabkan masjid itu mempunyai sifat wakaf yang abadi dan langgeng. Artinya, masjid itu selama-lamanya harus digunakan untuk beribadah umat Islam. Sebuah masjid tidak boleh dibongkar kecuali dengan tujuan pembongkaran dan tidak boleh dipindahkan. Jika ada sebuah tempat yang memiliki masjid kemudian ditinggalkan oleh penduduknya sehingga masjid itu tidak digunakan lagi untuk beribadah, maka dilarang juga untuk dibongkar. ${ }^{3}$

Fenomena awal perkembangan perwakafan di Indonesia sebagaimana gambaran di atas masih menguat hingga sekarang. Walaupun sudah mulai berkembang beberapa nazhir atau lembaga pengelola wakaf yang ada, tetapi perkembangan wakaf

3 Abdul Ghofur Anshori, Hukum dan Praktek Perwakafan di Indonesia, (Yogyakarta:Pilar Media, 2005), 
saat ini terasa tidak sebanding dan sangat kurang dengan harapan dan misi utama wakaf dalam Islam itu sendiri. Tata kelola wakaf di Indonesia harusnya bisa mengejar ketertinggalan dengan negara-negara lain, mengingat mayoritas penduduknya adalah umat Islam. Sehingga dapat berkontribusi untuk pengembangan dan pemberdayaan sosial ekonomi masyarakat. 4

Problematika pengembangan wakaf di Indonesia dapat diidentifikasi dari beberapa aspek, yaitu pertama, pemahaman masyarakat tentang hukum wakaf. Pada umumnya, masyarakat masih memahami hukum wakaf lebih bersifat tradisional, baik dari segi rukun dan syarat wakaf, maupun maksud disyariatkannya wakaf. Pada saat ini, cukup banyak masyarakat yang memahami bahwa benda yang dapat diwakafkan hanyalah benda tidak bergerak seperti tanah, bangunan, dan lain- lainnya. Sehingga, peruntukannya sangat terbatas, seperti untuk masjid, musholla, rumah yatim piatu, madrasah, sekolah, dan sejenisnya.

Kedua, tentang tatakelola wakaf. Kelola wakaf yang belum maksimal dan salah urus berdampak pada adanya harta wakaf yang terlantar, bahkan ada harta wakaf yang hilang. Dampak tersebut disebabkan antara lain wakaf tidak dikelola secara profesional dan produktif. Umat Islam (wakif) pada umumnya hanya mewakafkan tanah atau bangunan sekolah saja, sehingga kurang memikirkan biaya operasional aset wakaf tersebut bahkan upaya untuk menciptakan keuntungan dari kelola aset wakaf tersebut. Oleh karena itu, kajian mengenai manajemen pengelolaan wakaf ini sangat penting dalam upaya untuk memberdayakan sosial ekonomi umat.

Ketiga, tentang eksistensi nazhir. Nazhir adalah salah satu unsur penting dalam perwakafan. Berfungsi atau tidaknya intitusi wakaf sangat tergantung pada kemampuan nazhir. Di beberapa negara yang telah mengembangkan wakaf dengan profesional, wakaf dikelola oleh nazhir yang profesional. Di Indonesia, pengelolaan wakaf masih dalam proses pengembangan dan pada umumnya wakaf dikelola belum maksimal. Akibatnya, dalam berbagai kasus ada sebagian nazhir yang kurang memegang amanah, sehingga mereka melakukan penyimpangan dalam pengelolaan,

4 Uswatun Hasanah, “Wakaf Produktif Untuk Kesejahteraan dalam Perspektif Hukum Islam di Indonesia", dalam Pidato Pengukuhan Guru Besar, Universitas Indonesia, 6 April 2009. 
kurang melindungi harta wakaf, muncul sengketa wakaf antara beberapa pihak dan kecurangan-kecurangan lainnya.

Persoalan-persoalan penting dalam gambaran pengelolaan wakaf di atas tentu membutuhkan perhatian dan penanganan serius. Selama penanganan problem wakaf belum diatasi dengan baik, maka institusi wakaf tidak mampu memberikan kemanfaatan bagi mauquf'alaih sebagaimana misi utamanya. Padahal, secara kuantitatif, potensi wakaf sangat tinggi. Hal ini berdasar data yang dihimpun Kementerian Agama RI melalui Direktorat Pemberdayaan Wakaf tahun 2015. Jumlah tanah wakaf di Indonesia mencapai 4.142.464.287,906 meter persegi atau 414.246 hektare lebih yang tersebar di 435.395 lokasi di seluruh Indonesia. Jumlah tanah wakaf di Indonesia yang begitu besar juga dibarengi dengan sumber daya manusia (human capital) yang sangat besar pula, mengingat Indonesia merupakan negara yang memiliki jumlah penduduk mayoritas muslim.

Belum lagi adanya potensi wakaf bersumber dari donasi masyarakat yang disebut dengan wakaf uang (cash waqf). Jenis wakaf ini membuka peluang besar bagi penciptaan investasi dalam pengelolaan wakaf, yang hasilnya dapat dimanfaatkan pada bidang keagamaan, pendidikan, dan pelayanan sosial. Wakaf jenis ini lebih bernilai benefit daripada wakaf benda tak bergerak, seperti tanah. ${ }^{5}$ Jenis wakaf ini dalam konteks kelembagaan dan perkembangan ekonomi syari'ah sejalan dengan tumbuhnya model-model instrumen dan institusi ekonomi syari'ah seperti Bank Muamalah Indonesia (BMI), Bank Syari'ah Mandiri, Unit Usaha Syari'ah (UUS) yang terdapat dalam perbankan konvensional, Bank Pembiayaan Rakyat (BPR) Syariah dan lembaga keuangan mikro syari' ah seperti Baitul Mal wa Tamwil (BMT) dan lainnya.

Asumsi di atas tampaknya sesuai dengan realitas perkembangan wakaf di Indonesia yang mayoritas masih dalam level wakaf konsumtif yang keperuntukannya juga sebagian besar untuk sasaran sosial keagamaan khususnya pesantren, madrasah

\footnotetext{
${ }^{5}$ Mustafa Edwin Nasution \& Uswatun Hasanah, Wakaf Tunai Inovasi Finansial Islam: Peluang dan Tantangan Dalam Mewujudkan Kesejahteraan Umat, (Jakarta: Pusat Kajian Timur Tengah dan Islam Universitas Indonesia bekerja sama dengan Bank Indonesia, Serta Departemen Agama RI, 2006), 41-43.
} 
atau masjid/musolla. ${ }^{6}$ Walaupun demikian ada upaya dan ikhtiyar lebih untuk mewujudkan dan melakukan transformasi pemberdayaan wakaf berbasis masjid yang tadinya hanya berdimensi sosial keagamaan menuju dimensi sosial ekonomi. Hal ini mulai terjadi di lokasi pemberdayaan aset wakaf berbasis Masjid di beberapa daerah termasuk di Masjid Besar Imam Ulomo, Sampung Ponorogo. ${ }^{7}$

Adapun alasan pemilihan lokasi pengabdian berbasis masjid di Masjid Besar Imam Ulomo Sampung Ponorogo sebagai mitra pengabdian adalah ikhtiyar mewujudkan Masjid yang jauh dari perkotaan dan berada di pelosok untuk tidak hanya sebagai pusat sosial keagamaan tetapi juga diupayakan menjadi masjid yang maju dan progresif secara sosial-ekonomi bahkan menjadi contoh bagi masjid di pedalaman lainnya.

Mewujudkan usaha Masjid Besar Imam Ulomo, Sampung, Ponorogo sebagai pusat sosial masyarakat berbasis wakaf membutuhkan ihktiyar upaya yang serius. Banyak sisi yang perlu diadvokasi dan dikembangkan, termasuk transparansi dan pelaporan keuangan wakaf. Berpijak pada pemikiran di atas, artikel ini mengambil fokus "Masjid Wakaf dan Transformasi Sosial Umat di Masjid Besar Imam Ulomo Sampung Ponorogo." Pengabdian ini bertujuan sebagai upaya pembangunan masyarakat Islam terkait perubahan model pengelolaan wakaf, dari tradisional menjadi profesional. Dari konsumtif menuju produktif.

\section{B. Kajian Teori Pendekatan Asset Based Communities Development (ABCD) dalam Pemberdayaan Berbasis Masjid}

Tatakelola wakaf menjadi perhatian tersendiri dewasa ini. Tatakelola wakaf yang belum maksimal dan salah urus berdampak pada adanya harta wakaf yang terlantar, bahkan ada harta wakaf yang hilang. Dampak tersebut disebabkan antara lain wakaf tidak dikelola secara profesional dan produktif.

Realitasnya, umat Islam (wakif) pada umumnya hanya mewakafkan tanah atau bangunan, masjid atau mushola, sehingga kurang memikirkan biaya operasional aset wakaf tersebut bahkan upaya untuk menciptakan keuntungan dari kelola aset wakaf

\footnotetext{
${ }^{6}$ Kementerian Agama, Direktorat Pengembangan Zakat dan Wakaf. Paradigma Baru Wakaf di Indonesia. (Jakarta: Direktorat Jendreral Bimbingan Masyarakat Islam dan Penyelenggaraan Haji, 2015).

7 Obsevasi pada 14 Agustus 2016.
} 
tersebut. Selama penanganan problem wakaf belum diatasi dengan baik, maka institusi wakaf tidak mampu memberikan kemanfaatan bagi mauquf 'alaih sebagaimana misi utamanya.

Dengan demikian, untuk mengembangkan tatakelola aset wakaf berbasis masjid secara produktif, perlu konsep dan mekanisme tatakelola wakaf yang dikembangkan dengan cara integratif. Dengan empat pilar tatakelola wakaf baik dengan cara menghimpun sumber wakaf yang inovatif, mengelola aset wakaf secara produktif, menyaurkan hasil wakaf dengan memberdayakan dan melaporkan wakaf secara transparan dan akuntabel menjadi pilihan yang dilakukan untuk mitra pengabdian. ${ }^{8}$

Skema Mekanisme Tatakelola Wakaf

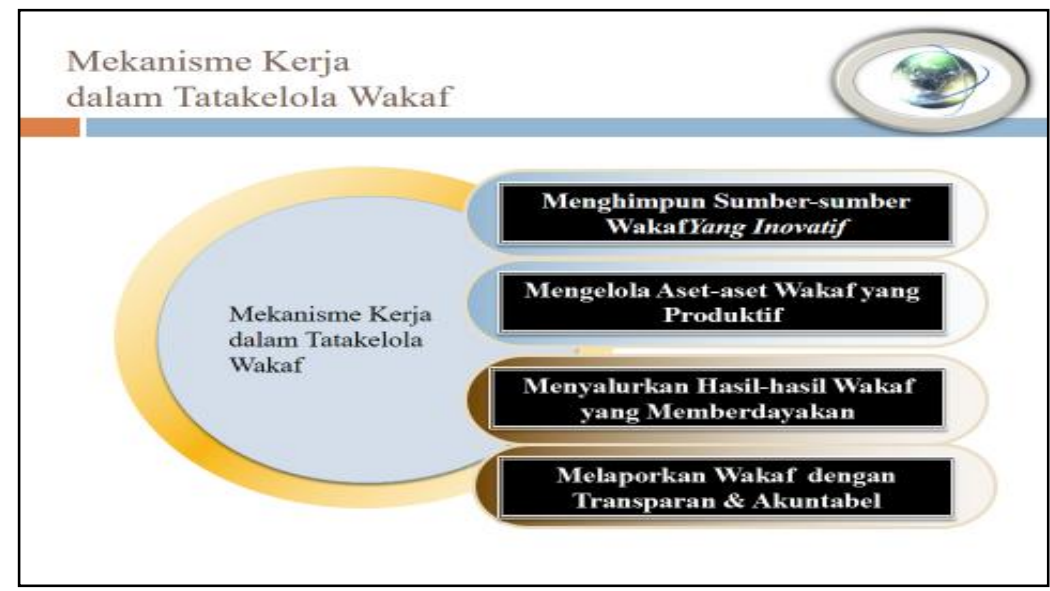

Salah satu bentuk pengabdian dosen kepada masyarakat adalah penyelenggaraan pengabdian masyarakat berbasis masjid. Model dan pendekatan pengabdian di berbagai perguruan tinggi memiliki paradigma pengabdian yang beragam sesuai dengan dinamika kampus dan masyarakat masing-masing. Pengabdi melalui program ini berikhtiyar mengembangkan Paradigma Transformatif untuk program pengabdian masyarakat berbasis masjid. Program ini berparadigma Transformatif, yaitu kegiatan penerjemahan, penerapan, dan pengembangan pengetahuan, keterampilan, dan sikap dalam kehidupan bermasyarakat yang ditujukan menciptakan, membangun, dan memelihara perubahan yang menjunjung nilai-nilai

${ }^{8}$ Huda, Mengalirkan Manfaat Wakaf. 
luhur keadilan, kesetaraan, dan keseimbangan. Dengan demikian, dosen diharapkan bisa menjadi agen perubahan dan sekaligus mampu menemukan, melahirkan, memfasilitasi masyarakat sebagai agen perubahan atas diri mereka sendiri.

Usaha perbaikan kualitas kehidupan masyarakat dengan pola pembangunan yang menempatkan manusia menjadi pelaku utama sudah dilakukan di Indonesia. Mengingat pola ini masih menjadi rintisan maka dukungan berbagai pihak sangat dibutuhkan. Perguruan tinggi sebagai salah satu lembaga pendidikan memiliki peran yang sangat strategis untuk ikut serta upaya ini. Sebuah usaha yang memastikan bahwa kegiatan pembangunan selayaknya menempatkan posisi manusia dapat berkembang kapasitasnya sesuai dengan segala potensi dan aset yang dimiliki. Lebih dari itu, perguruan tinggi dapat berperan dalam mewujudkan bagaimana terbentuknya masyarakat Indonesia yang memiliki kepedulian dan keaktifan sebagai warga negara.

Pendekatan Asset Based Communities Development (ABCD) adalah jenis pendekatan yang dipakai dalam pemberdayaan masyarakat, khususnya dalam konteks ini pemberdayaan aset wakaf berbasis masjid. ABCD merupakan sebuah pendekatan dalam pengembangan masyarakat yang berada dalam aliran besar mengupayakan terwujudkan sebuah tatanan kehidupan sosial dimana masyarakat menjadi pelaku dan penentu upaya pembangunan di lingkungannya atau yang seringkali disebut dengan Community-Driven Development (CDD).

Upaya pengembangan warga masjid harus dilaksanakan dengan sejak dari awal menempatkan warga masjid untuk mengetahui apa yang menjadi kekuatan yang dimiliki serta segenap potensi dan aset yang dipunyai yang potensial untuk dimanfaatkan. Hanya dengan mengetahui kekuatan dan aset, diharapkan warga masjid mengetahui dan bersemangat untuk terlibat sebagai aktor dan oleh karenanya memiliki inisiatif dalam segala upaya perbaikan.

Dengan mengetahui kekuatan dan set yang dimiliki, serta memiliki agenda perubahan yang dirumuskan bersama, persoalan keberlanjutan sebuah program perbaikan kualitas kehidupan diharapkan dapat diwujudkan. Melalui pendekatan $\mathrm{ABCD}$, warga masjid difasilitasi untuk merumuskan agenda perubahan yang mereka anggap penting. Kegiatan yang dilaksanakan dosen ini menjadi sangat penting untuk 
memastikan bahwa warga pesantren berkesempatan untuk turut serta sebagai penentu, agenda perubahan tersebut. Tatkala warga masjid telah menentukan agenda perubahan tersebut, maka apapun rencana tersebut, warga masjid akan berjuang untuk mewujudkannya. Oleh karena itu, kegiatan pengabdian adalah kegiatan stimulasi dan fasilitasi terjadi proses ini.

Pendekatan ini dianggap kritis yang masuk dalam lingkup pengembangan masyarakat berbasis pada kekuatan dan aset yang dimiliki masyarakat. Sebuah pendekatan yang sangat menekankan kepada kemandirian masyarakat dan terbangunnya sebuah tatanan dimana warga aktif menjadi pelaku dan penentu pembangunan.

Point yang perlu digarisbawahi dalam paradigma dan prinsip yang dimiliki oleh pendekatan $\mathrm{ABCD}$ adalah bahwa semuanya mengarah kepada konteks pemahaman dan internalisasi aset, potensi, kekuatan, dan pendayagunaannya secara mandiri dan maksimal. Masing-masing prinsip mengisyaratkan penyadaran akan keberadaan kekuatan dan energi positif yang dimiliki "masyarakat" yang harus diidentifikasi, diketahui, difahami, diinternalisasi, untuk kemudian dimobilisasi oleh masyarakat sendiri dalam kerangka menuju peningkatan kesejahteran dan keberdayaan semua elemen komunitas-masyarakat.

Adapun paradigma dan prinsip-prinsip pengembangan masyarakat berbasis aset $(\mathrm{ABCD})$ dapat dijelaskan sebagai berikut: ${ }^{9}$

1. Setengah Terisi Lebih Berarti (Halffull and half empty)

2. Semua punya potensi (No body has nothing)

3. Partisipasi (Participation)

4. Kemitraan (Partnership)

5. Penyimpangan positif (Positive Deviance)

6. Berasal dari dalam masyarakat (Endogenous)

7. Mengarah pada sumber energi (Heliotropic)

9 Tim Penulis, Panduan KKN ABCD, (Surabaya: UINSA Press, 2015), 120 
Adapun secara teknis mekanisme pemberdayaan dengan memakai proses Appreciative Inquiry (AI) terdiri dari 4 tahap yaitu Discovery, Dream, Design dan Destiny atau sering disebut Model atau Siklus 4-D. ${ }^{10}$

\section{Discovery}

Tahap Discovery adalah proses pencarian yang mendalam tentang hal-hal positif, hal-hal terbaik yang pernah dicapai, dan pengalaman-pengalaman keberhasilan di masa lalu. Proses ini dilakukan dengan wawancara apresiatif.

\section{Dream}

Berdasarkan informasi yang diperoleh dari tahap sebelumnya, orang kemudian mulai membayangkan masa depan yang diharapkan. Pada tahap ini, setiap orang mengeksplorasi harapan dan impian mereka baik untuk diri mereka sendiri maupun untuk organisasi. Inilah saatnya orang-orang memikirkan halhal besar dan berpikir out of the box serta membayangkan hasil-hasil yang ingin dicapai.

\section{Design}

Pada tahap Design ini, orang mulai merumuskan strategi, proses dan sistem, membuat keputusan dan mengembangkan kolaborasi yang mendukung terwujudnya perubahan yang diharapkan. Pada tahap ini semua hal positif di masa lalu ditransformasi menjadi kekuatan untuk mewujudkan perubahan yang diharapkan (dream).

\section{Destiny}

Tahap Destiny adalah tahap dimana setiap orang dalam organisasi mengimplementasikan berbagai hal yang sudah dirumuskan pada tahap Design. Tahap ini berlangsung ketika organisasi secara kontinyu menjalankan perubahan, memantau perkembangannya, dan mengembangkan dialog, pembelajaran dan inovasi-inovasi baru. Berikut gambaran siklus pengeloaan berdasarkan 4-D. ${ }^{11}$

${ }^{10}$ Tim Penulis, Panduan KKN ABCD, (Surabaya: UINSA Press, 2015), 122 20.

11 Christopher Dureau, Pembaharu dan Kekuatan Lokal Untuk Pembangunan (ACCESSPhase II, 2013), 


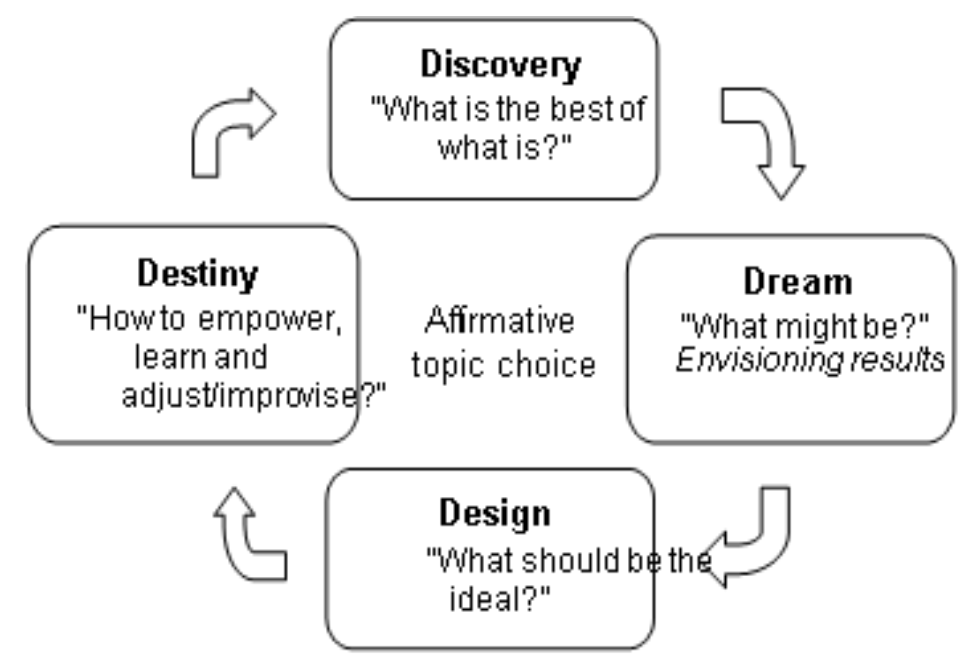

\section{Implementasi Pengabdian Berbasis Masjid dan Transformasi Sosial Umat 1. Gambaran Umum Lokasi Pengabdian}

Masjid Besar Imam Ulomo Sampung Ponorogo Jawa Timur didirikan pada tahun 1927 oleh Kyai Imam Ulomo yang merupakan naip pertama di Kecamatan Sampung dan mewakafkan sebagian tanahnya untuk dibangun masjid. Pendirian masjid didasarkan atas keprihatinan Kyai Imam Ulomo melihat daerah Sampung yang tidak memiliki masjid sebagai sarana beribadah umat muslim yang ada. Selain untuk sarana ibadah, masjid tersebut diharapkan adanya kerukunan antar masyarakat. Sepeninggal beliau kepengurusan masjid besar berganti-ganti generasi namun masih juga tidak menambah kepercayaan masyarakat terhadap kepengurusan masjid.

Saat ini potensi masjid besar Imam Ulomo sangat prospektif, seperti jama'ah masjid yang banyak, dengan aktivitas peribadatan dalam masjid yang masih aktif. Aset wakaf terus berkembang, dana infak dan sedekah lebih menjanjikan. Hasil produktivitas sawah wakaf juga mulai berkembang. Masjid Besar Imam Ulomo merupakan masjid di kecamatan Sampung yang memiliki fungsi sebagai pusat dakwah, pusat kegiatan keagamaan dan tempat pembinaan jama'ah. ${ }^{12}$

Di samping realitas mitra dampingan di atas, terbentuknya susunan nadzir yang baru mulai menumbukan kesadaran wakaf pada masyarakat sehingga banyak wakif-

12 Observasi pada 7 September 2016. 
wakif baru untuk mencapai tujuan kemakmuran masjid besar Imam Ulomo. Nadzir baru ini menahkodari pengelolaan aset wakaf berbasis masjid dengan lebih profesional dibanding sebelumnya. ${ }^{13}$

Selain untuk sarana ibadah, dengan didirikannya masjid tersebut diharapkan ada kerukunan antar masyarakat yang kepengurusannya masih dilakukan oleh Kyai Imam Ulomo. Sepeninggalan beliau kepengurusan masjid besar berganti-ganti generasi namun masih juga tidak menambah kepercayaan masyarakat terhadap kepengurusan masjid. Setelah sekian lama kepengurusan masjid besar Imam Ulomo terbengkalai kemudian pada tahun 2009 dibentuklah kepengurusan baru yang dilakukan secara musyawarah dengan masyarakat, ulama-ulama serta pengurus masjid atau mushola yang berada di sekitar desa Sampung maka terbentuklah susunan nadzir baru yang didukung dan didorong dari semua lapisan masyarakat. Saat ini Nadzir masjid besar Imam Ulomo di pimpin oleh Drs. Abdul Aziz.

Dengan adanya susunan nadzir yang baru mulai menumbukan kesadaran wakaf pada masyarakat sehingga banyak wakif-wakif baru untuk mencapai tujuan kemakmuran masjid besar Imam Ulomo. Pada tahun 2005 seorang wakif yang bernama Nur Hasyim berwakaf untuk pembuatan sumur alami sebagai sarana bersuci karena di Desa Sampung masyarakat hanya mengandalkan air dari PDAM yang terkadang tidak mengalir. Selanjutnya ada juga wakaf tanah pertanian berupa sawah pada tahun 2009 sistem penggarapannya ditanami sesuai dengan musimnya. ${ }^{14}$

Aset wakaf yang dimiliki Masjid Besar Imam Ulama terdiri dari tanah wakaf seluas $750 \mathrm{~m}^{2}$ pada tanggal 27 Mei 1987, yang diwakafkan oleh Kyai Imam Ulomo selaku naib pertama di Kecamatan Sampung. Walaupun dengan keterbatasan baik dengan tenaga maupun materi beberapa jamaah sekitar masjid juga sangat peduli pada saat pembangunan masjid wakaf ini mulai dari memberikan semen, batu bata dan tenaga secara cuma-cuma. ${ }^{15}$

13 Tim Penulis, Album Masjid Besar Imam Ulomo Sampung (Sampung: Takmir Masjid, 2011).

14 Wawancara pendahuluan dengan Drs. Abdul Aziz, nadzir Masjid Besar Imam Ulomo pada tanggal 6 Agustus 2016 dan observasi awal pada 14 Agustus 2016.

15 Wawancara dengan Bpk Drs. Abdul Aziz pada 12 Oktober 2016. 
Berawal dari kesadaran jamaah itulah, akhirnya bapak Nur Hasyim merelakan sedikit hartanya membuat sumur bor alami dengan tujuan untuk persediaan air bersih jama'ah. Sampai akhirnya tahun 2009 Bapak Marsudi mewakafkan tanah pertanian berupa sawah dengan luas $1500 \mathrm{~m}^{2}$ yang saat ini masih produktif, yang hasilnya akan disalurkan untuk donasi anak yatim dan miskin di wilayah Kecamatan Sampung. ${ }^{16}$

Potensi jama'ah masjid yang banyak, dengan segelintir aktivitas peribadatan dalam masjid yang masih aktif. Di luar konteks wakaf, dana infak dan sedekahnya pun lebih menjanjikan. Jika hasil produktivitas sawah dalam setahun sekitar $5-5,5$ juta, maka masjid memiliki kecukupan dana yang lebih.

\section{Tabel Aset Wakaf Masjid}

\begin{tabular}{|l|l|l|}
\hline No & Aset Wakaf Masjid & Jumlah \\
\hline 1 & Sumur air minum & 1 \\
\hline 2 & Tanah wakaf masjid & $750 \mathrm{~m}^{2}$ \\
\hline 3 & Tanah sawah & $1500 \mathrm{~m}^{2}$ \\
\hline & Jumlah & $2250 \mathrm{~m}^{2}$ \\
\hline
\end{tabular}

\section{Strategi Pelaksanaan Pengabdian Berbasis Masjid dan Transformasi Sosial Umat}

Pemberdayaan sebagai proses menurut Edi Suharto, memiliki lima dimensi yaitu: Pertama, enabling yaitu menciptakan suasana atau iklim yang memungkinkan potensi masyarakat berkembang secara optimal. Kedua, empowering adalah penguatan pengetahuan dan kemampuan yang dimiliki masyarakat dalam memecahkan masalah dan memenuhi kebutuhan-kebutuhannya. Ketiga, protecting yaitu melindungi masyarakat terutama kelompok-kelompok lemah agar tidak tertindas oleh kelompokkelompok kuat dan dominan, menghindari persaingan yang tidak seimbang, mencegah terjadinya eksploitasi kelompok kuat terhadap yang lemah. Keempat, supporting yaitu pemberian bimbingan dan dukungan kepada masyarakat lemah agar mampu menjalankan peran dan fungsi kehidupannya. Dan kelima, fostering yaitu memelihara

16 Wawancara dengan Bpk Nur Hasyim pada Oktober 2016. 
kondisi kondusif agar tetap terjadi keseimbangan distribusi kekuasaan antara berbagai kelompok masyarakat. ${ }^{17}$

Mengacu pada statemen di atas, serta kondisi yang diinginkan dari program pengabdian dan penguatan kapasitas nadzir wakaf produktif berbasis masjid maka strategi yang kami agendakan adalah sebagai berikut:

\section{Tabel Strategi Pemberdayaan}

E. Anaisis Hasil Pengabdian Berbasis Masjid dan Transformasi Sosial Umat

\begin{tabular}{|l|l|l|l|l|}
\hline NO & $\begin{array}{l}\text { KONDISI } \\
\text { AWAL }\end{array}$ & $\begin{array}{l}\text { BENTUK DAN } \\
\text { STRTEGI } \\
\text { KEGIATAN }\end{array}$ & $\begin{array}{l}\text { SUBYEK } \\
\text { SASARAN }\end{array}$ & $\begin{array}{l}\text { INDIKATOR } \\
\text { KONDISI YANG } \\
\text { DIINGINKAN }\end{array}$ \\
\hline 1. & $\begin{array}{l}\text { Minim mindset } \\
\text { baru tentang } \\
\text { hukum dan } \\
\text { institusi nadzir } \\
\text { wakaf produktif }\end{array}$ & $\begin{array}{l}\text { Melakukan } \\
\text { sosialisasi tentang } \\
\text { paradigma baru } \\
\text { hukum wakaf } \\
\text { dan institusi } \\
\text { nazhir wakaf } \\
\text { produktif }\end{array}$ & $\begin{array}{l}\text { Nadzir, } \\
\text { Wakif dan } \\
\text { Maukuf } \\
\text { Alaih } \\
\text { (masyarakat } \\
\text { sekitar) }\end{array}$ & $\begin{array}{l}\text { Tumbuh mindset } \\
\text { hukum wakaf yg } \\
\text { bernuansa formal } \\
\text { administratif dan } \\
\text { esensial serta nadzir } \\
\text { yg kompeten, } \\
\text { kolegial dan bemitra }\end{array}$ \\
\hline 2. & $\begin{array}{l}\text { Menghimpun } \\
\text { sumber wakaf } \\
\text { masih pasif }\end{array}$ & $\begin{array}{l}\text { Sosialisasi } \\
\text { penghimpunan } \\
\text { sumber wakaf } \\
\text { perspektif } \\
\text { fundraising }\end{array}$ & $\begin{array}{l}\text { Nadzir dan } \\
\text { masyarakat } \\
\text { sekitar }\end{array}$ & $\begin{array}{l}\text { Menghasilkan } \\
\text { sumber wakaf yang } \\
\text { variatif }\end{array}$ \\
\hline 3. & $\begin{array}{l}\text { Usaha } \\
\text { pengelolaan aset } \\
\text { wakaf masih } \\
\text { bersifat statis } \\
\text { dan konsumtif }\end{array}$ & $\begin{array}{l}\text { sosialisasi } \\
\text { manajemen kelola } \\
\text { wakaf produktif }\end{array}$ & $\begin{array}{l}\text { Nadzir dan } \\
\text { masyarakat } \\
\text { sekitar }\end{array}$ & $\begin{array}{l}\text { Tercipta } \\
\text { produktivitas aset } \\
\text { wakaf }\end{array}$ \\
\hline
\end{tabular}

Pelaksanaan kegiatan pengabdian dengan fokus pengabdian “Masjid Wakaf dan Transformasi Sosial Umat di Masjid Besar Imam Ulomo Sampung Ponorogo dilaksanakan dalam 2 tahap. Tahap pertama kegiatan FGD wakaf produktif, sosialisasi penguatan kelembagaan nadzir wakaf dan tahap kedua berbentuk pelatihan dan pendampingan aset wakaf produktif.

Berikut penjelasan terperinci dari masing-masing kegiatan inti:

\section{Focus Group Discussion (FGD)}

17 Edi Suharto, Pendekatan Pekerjaan Sosial Dalam Pemberdayaan Masyarakat Miskin: Konsep, Indikator dan Strategi (Malang: TP, 2004). 
Focus Group Discussion (FGD) merupakan diskusi terfokus seputar penguatan kelembagaan nadzir dan pengembangan produktifitas aset wakaf masjid. Kegiatan ini dilaksanakan pada 30 Oktober 2016, di serambi depan Masjid Besar Imam Ulomo, Sampung. Dalam FGD ini, dimoderatori oleh Dr. Miftahul Huda, M.Ag. FGD ini tidak hanya mengejar interaksi dan dinamika kelompok, tetapi fokus pada tema diskusi, sehingga moderator akan selalu berusaha mengembalikan diskusi ke "fokus tema wakaf". Moderator memang dituntut untuk mencairkan suasana (ice breaking) agar diskusi tidak berlangsung kaku.

Dalam FGD ini, moderator menyampaikan pengantar diskusi bahwa wakaf produktif merupakan upaya menciptakan sumber pendanaan/kapital berbasis aset wakaf yang dikelola dengan membangun unit-unit usaha yang mendatangkan surplus (keuntungan), dan menggunakan surplus itu untuk pemberdayaan sosial ekonomi atau layanan sosial keagamaan.

Pengelolaan dan pengembangan harta benda wakaf dilakukan secara produktif antara lain dengan cara pengumpulan, investasi, penanaman modal, produksi, kemitraan, perdagangan, agrobisnis, pertambangan, perindustrian, pengembangan teknologi, pembangunan gedung, apartemen, rumah susun, pasar swalayan, pertokoan, perkantoran, sarana pendidikan ataupun sarana kesehatan dan usaha-usaha yang tidak bertentangan dengan syariah (UU Wakaf). Berikut bagan anasir Wakaf Produktif:

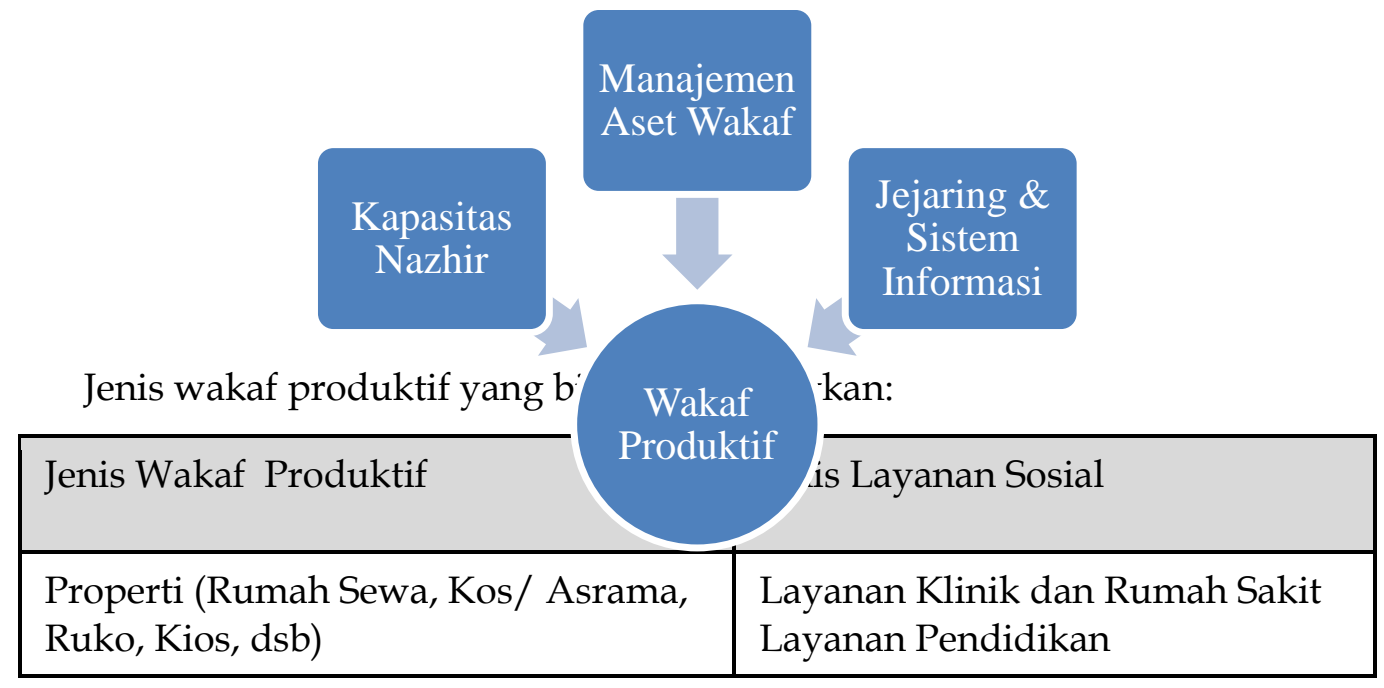




\begin{tabular}{|l|l|}
\hline Pertanian dan Perkebunan (Sawah, & Layanan Rekreasi (Taman \\
Jati, Kebun Kelapa, Kebun Salak, dsb) & bermain) \\
Usaha Perdagangan (SPBU, & Layanan Umum (Pemakaman, \\
Minimarket, Toko Kelontong, Grosir, & Jalan, jembatan, kolam renang) \\
dsb) & Layanan Ibadah (masjid dan \\
Usaha Home Industri (Batik, Mainan, & musola) \\
Makanan Kecil, dsb) & Layanan Santunan (Kotak amal \\
Usaha Jasa (Kurir, Antar Jemput, dsb) & umum) \\
Micro finance (Kopsyah, BMT) & Layanan Perdagangan \\
DLL & (penginapan, pasar, rumah \\
& singgah) \\
\hline
\end{tabular}

Beberapa gagasan dan diskusi yang muncul dan relevan untuk ditindaklanjuti dalam FGD ini, yaitu: 18

a) Terkait pemberdayaan jamaah masjid wakaf untuk diberdayakan mengelola Sumber Daya Hutan Desa. Bagaimana mengelola tanah hutan desa tersebut agar produktif bersama, akan ditanami apa atau diadakan training apa, serta upaya adanya suntikan dana untuk pengelolaan sumber daya hutan desa tersebut. Usulan ini disampaikan oleh Pak Nur.

b) Upaya memanfaatkan ruang kosong di gudang masjid wakaf sebagai tempat budidaya jamur tiram. Mulai dari pelatihan penyediaan media tanamnya hingga sampai pada penanaman. Usulan ini disampaikan Pak Joko

c) Upaya pemanfaatan lahan kosong disekitar masjid wakaf sebagai kolam ikan produktif. Upaya yang perlu disiapkan adalah media kolam, sirkulasi air, pemberian benih ikan dan pemeliharaan secara periodik. Usulan ini disampaikan oleh Mbah Nur.

d) Terkait upaya pendampingan terhadap musola disekitaran masjid wakaf yang memiliki tanah wakaf namun terkendala administrasi belum terdaftar di badan wakaf Indonesia. Bagaimana kelembagaannya agar asetnya dapat dikelola dengan maksimal Penguatan status kelembagaan nazir, sehingga dapat menjadi bagian dari jaringan Nadzir di Kabupaten Ponorogo. Usulan ini disampaiakn Pak Aziz.

18 Data dokumen pada FGD September 2016 
e) Terkait dengan adanya aset wakaf musola disekitar masjid wakaf yang status sertifikat tanahnya masih ikut bagian pihak yang mewakafkan. Dan upaya sertifikasi mandirinya berhenti ditengah jalan sejak 2014. Apakah ada solusi dan pendapingan dari kasus ini. Sementara ikrar wakaf di KUA belum dilaksanakan dan konfirmasi kejelasan status tanah ke pihak BPN. Usulan ini disampikan Pak Wuryoso.

Maka, berdasarkan diskusi dan sharing dari para nadzir, takmir dan jamaah masjid wakaf, berdasarkan skala prioritas diputuskan 2 program yang akan dilaksanakan pendampingan, yaitu: 1) Sosialisasi administrasi dan penguatan kelembagaan nadzir, 2) Training pengelolaan wakaf produktif pengembangan aset pertanian dan perikanan.

Beberapa point penting dari kegiatan FGD, dapat disimpulkan sebagai berikut:

a. Dari memahami esensi wakaf bersifat sosial keagamaan ritual menuju wakaf bersifat sosial ekonomi

b. Dari landasan wakaf dalam kitab fikih saja tapi juga harus menuju landasan wakaf fikih indonesia (peraturan perundangan)

c. Dari memahami wakaf bersifat informal menuju wakaf formal yustitial/administratif

Maka, diera modern perlu dibangun mindset paradigma baru pengelolaan wakaf produktif, yaitu:

a. Dari menghimpun sumber wakaf pasif menuju menghimpun sumber wakaf aktif bahkan kreatif

b. Dari mengelola aset wakaf konsumtif menuju mengelola aset wakaf produktif bahkan benefit

c. Dari menyalurkan hasil wakaf cuma-cuma/charity menuju menyalurkan hasil wakaf yang memberdayakan bahkan advokatif

d. Dari melaporkan hasil wakaf yang tertutup menuju melaporkan hasil wakaf terbuka/ transparan bahkan akuntabel.

\section{Sosialisasi Administrasi Wakaf dan Penguatan Kelembagaan Nadzir}


Kegiatan sosialisasi administrasi dan penguatan kelembagaan nadzir di awali dengan koordinasi dengan ketua nadzir sehari sebelumnya. Sosialisasi paradigma tata kelola wakaf produktif difokuskan pada penjelasan dan pemahaman terkait konsep dan aplikasi wakaf produktif serta bagaimana tata kelola aset wakaf agar semakin produktif. Sementara sosialisasi penguatan Kelembagaan Nadzir wakaf difokuskan pada penjelasan dan penjabaran fungsi nadzir dan kelembagaan nadzir sebagai ujung tombak dalam mewujudkan wakaf produktif.

Kegiatan inti sosialisasi Administrasi Wakaf dan Pelatihan Penguatan Kelembagaan Nadzir dilaksanakan pada 30 November 2016 dengan menghadirkan 2 nara sumber, yaitu: 1. Drs. KH. Muhsin (Ketua Badan Wakaf Indonesia Perwakilan Ponorogo). 2. Drs. Irchamni (Ketua Asosiasi Nadzir Kabupaten Ponorogo).

Pembicara pertama, menyampaikan materi sosialisasi seputar paradigma baru dalam memahami wakaf, point pertama yang dapat disimpulkan sebagai berikut:

d. Dari memahami esensi wakaf bersifat sosial keagamaan ritual menuju wakaf bersifat sosial ekonomi

e. Dari landasan wakaf dalam kitab fikih saja tapi juga harus menuju landasan wakaf fikih indonesia (peraturan perundangan)

f. Dari memahami wakaf bersifat informal menuju wakaf formal yustitial/administratif

Sedangkan beberapa point tambahan lainnya terkait problem pengembangan wakaf produktif, yaitu:

e. Fasilitas Umum, dibangun oleh umat, di atas tanah hak milik pribadi.

f. Wakif telah mewakafkan tanahnya, namun nadzir belum memprosesnya sesuai dengan aturan yang ada, karena tidak ada dana dan/atau belum memahami prosedur dan aturannya.

g. Sudah Ikrar PPAIW tetapi belum bisa diproses di BPN, karena masih terdapat persyaratan yang belum terpenuhi.

h. Sudah selesai sertifikat wakaf, tetapi tidak terpantau

i. Fasilitas Umum, dibangun oleh umat, di atas tanah hak milik pribadi. 
j. Wakif telah mewakafkan tanahnya, namun nadzir belum memprosesnya sesuai dengan aturan yang ada, karena tidak ada dana dan/atau belum memahami prosedur dan aturannya.

k. Sudah Ikrar PPAIW tetapi belum bisa diproses di BPN, karena masih terdapat persyaratan yang belum terpenuhi.

1. Sudah selesai sertifikat wakaf, tetapi tidak terpantau

Pembicara kedua, menyampaikan materi sosialisasi seputar penguatan kelembagaan wakaf/nazhir. Nazhir dalam konteks wakaf dapat dipahami sebagai orang atau sekelompok orang yang bertanggungjawab untuk mengurusi, mengelola, menjaga dan mengembangkan barang wakaf. Nadzir menurut Undang-undang No.41 Tahun 2004 tentang Wakaf adalah pihak yang menerima harta benda wakaf dari wakif untuk dikelola dan dikembangkan sesuai dengan peruntukannya. ${ }^{19}$

Nadzir terdiri dari: 1) Nazhir perseorangan, 2) Nazhir Organisasi, dan 3) Nazhir Badan Hukum.

Nadzir perseorangan memiliki syarat, yaitu:
a. WNI
b. Beragama Islam
c. Dewasa
d. Amanah: dapat dipercaya
e. Mampu secara jasmani dan rohani
f. Tidak terhalang melakukan perbuatan hukum.

Sedangkan syarat nadzir organisasi dan badan hukum yaitu:

a. Pengurus organisasi / badan hukum tersebut memenuhi persyaratan sebagai nazhir perseorangan.

b. Bergerak dibidang sosial, pendidikan, kemasyarakatan, dan/atau keagamaan Islam.

c. Badan Hukum tersebut merupakan BHI yang dibentuk sesuai dengan peraturan perundang-undangan yg berlaku.

\footnotetext{
${ }^{19}$ Lihat Undang-undang No.41 Tahun 2004 tentang Wakaf
} 
Sementara itu, tugas Nazhir sesuai UU No. 41/2004 tentang Wakaf, yaitu:

1. Melakukan pengadministrasian harta benda wakaf;

2. Mengelola dan mengembangkan harta benda wakaf sesuai dengan tujuan, fungsi dan peruntukannya;

3. Mengawasi dan melindungi harta benda wakaf;

4. Melaporkan pelaksanaan tugas kepada Badan Wakaf Indonesia.

Beberapa gagasan dan diskusi sesi kedua yang muncul dan relevan untuk ditindaklanjuti, yaitu:

a. Bagaimana kelembagaan nadzir yang baik agar aset wakaf dapat dikelola dengan maksimal. Serta dapat menjadi bagian dari jaringan Nadzir di Kabupaten Ponorogo. Usulan ini disampaikan Pak Aziz.

b. Terkait dengan adanya perubahan status nadzir perseorangn untuk dirubah menjadi nadzir organisasi apa bisa? Dan bagaimana prosedurnya sehingga aset wakaf dapat dikelola semakin maksimal. Usulan ini disampikan Pak Hasyim.

Dengan pemaparan narasumber, diskusi dan tanya jawab maka dirumuskan kesimpulan inti materi kegiatan dalam beberapa point, yaitu:

a. Dari kelembagaan nadzir wakaf bersifat personal menuju kelembagaan nadzir wakaf kolegial (organisasi/yayasan/badan hukum/kelompok)

b. Dari kelembagaan nadzir wakaf tergantung satu orang (one man show) menuju pembagian berkarya wakaf manajerial

c. Dari kelembagaan nadzir wakaf tradisional menuju kelembagaan yang profesional

d. Dari pola kelembagaan nadzir wakaf parsial menuju pola jejaring/koordinasi

Berikut beberapa point terkait prosedur dan legalisasi wakaf, yaitu:

1. Proses Akad Ikrar Wakaf

- Idealnya ada pernyataan dari Ahli Waris untuk meminimalisir konflik di kemudian hari;

- Untuk nadzir baru harus didaftarkan dulu ke BWI baik perorangan maupun Badan Hukum/ Organisasi, melalui KUA Kecamatan Sampung; 
- Untuk nadzir NU dan Muhammadiyah sudah terdaftar di BWI Pusat;

- Untuk proses wakaf ke NU/ Muhammadiyah maka cukup dibuatkan AIW tanpa Bukti Pendaftaran dan tanpa Surat Pengesahan Nadzir dari PPAIW.

\section{Pendaftaran Nadzir}

- BWI sesuai kewenangannya dapat mengeluarkan Bukti Pendaftaran Nadzir untuk Nadzir yang baru dibentuk.

- Nadzir Perseorangan dapat didaftarkan ke BWI Perwakilan setelah proses AIW tuntas.

- Adapun Nadzir Organisasi/ Badan Hukum justru didaftarkan ke BWI Perwakilan terlebih dahulu sebelum menerima wakaf. (sebagaimana Nadzir Wakaf Uang).

3. Proses Wakaf

- Wakaf dengan Nadzir Perseorangan.

- Wakaf dengan Nadzir Badan Hukum/Organisasi

- Perseorangan didaftarkan setelah AIW

- Badan Hukum/Organisasi sebelum AIW

- Untuk NU/Muhammadiyah tidak perlu didaftarkan karena sudah terdaftar, jadi cukup AIW tanpa Pendaftaran Nadzir dan tanpa Pengesahan Nadzir.

3. Proses Wakaf

- Wakaf dengan Nadzir Perseorangan.

- Wakaf dengan Nadzir Badan Hukum/ Organisasi

- Perseorangan didaftarkan setelah AIW

- Badan Hukum/ Organisasi sebelum AIW

- Untuk NU/Muhammadiyah tidak perlu didaftarkan karena sudah terdaftar, jadi cukup AIW tanpa Pendaftaran Nadzir dan tanpa Pengesahan Nadzir.

Tahap selanjutnya dari program pengabdian ini adalah peningkatan produktifitas aset wakaf, bentuk kegiatannya adalah dengan pembuatan kolam ikan dan pemberian insentif budidaya ikan dan holtikultura. Kegiatan ini dilaksanakan pada Selasa, 27 Desember 2016. 
Hasil kegiatan pengabdian berbasis masjid yang dilaksanakan di Masjid Besar Imam Ulomo terdiri dari Focus Group Discussion (FGD), dan sosialisasi Administrasi Wakaf dan Pelatihan Penguatan Kelembagaan Nadzir terlaksana dengan baik dan sesuai target.

Adapun penjabarannya sebagai berikut: Untuk FGD, teridentifikasinya beberapa kebutuhan untuk pengembangan wakaf produktif di Masjid Besar Imam Ulomo, Sampung, seperti penguatan kapasitas nadzir, proses administrasi wakaf tanah, dan pengembangan aset wakaf secara produktif.

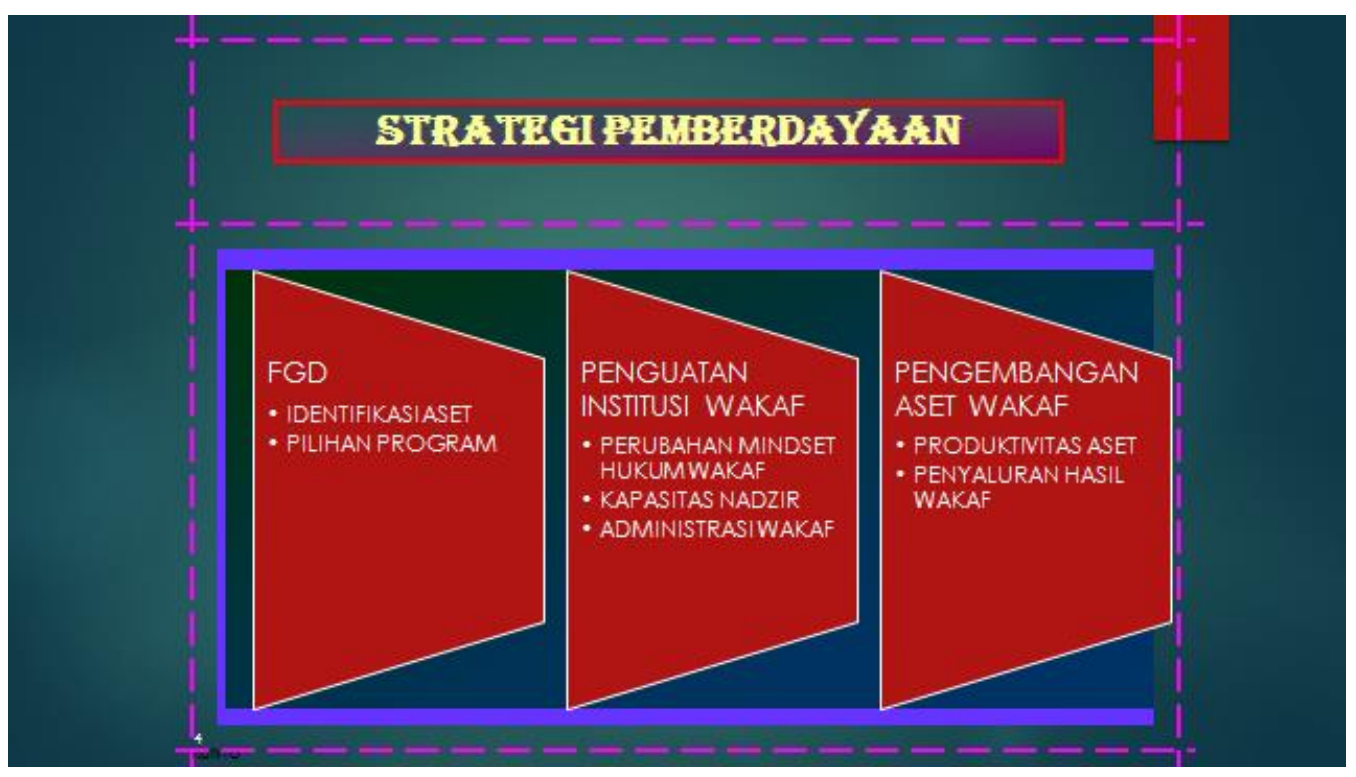




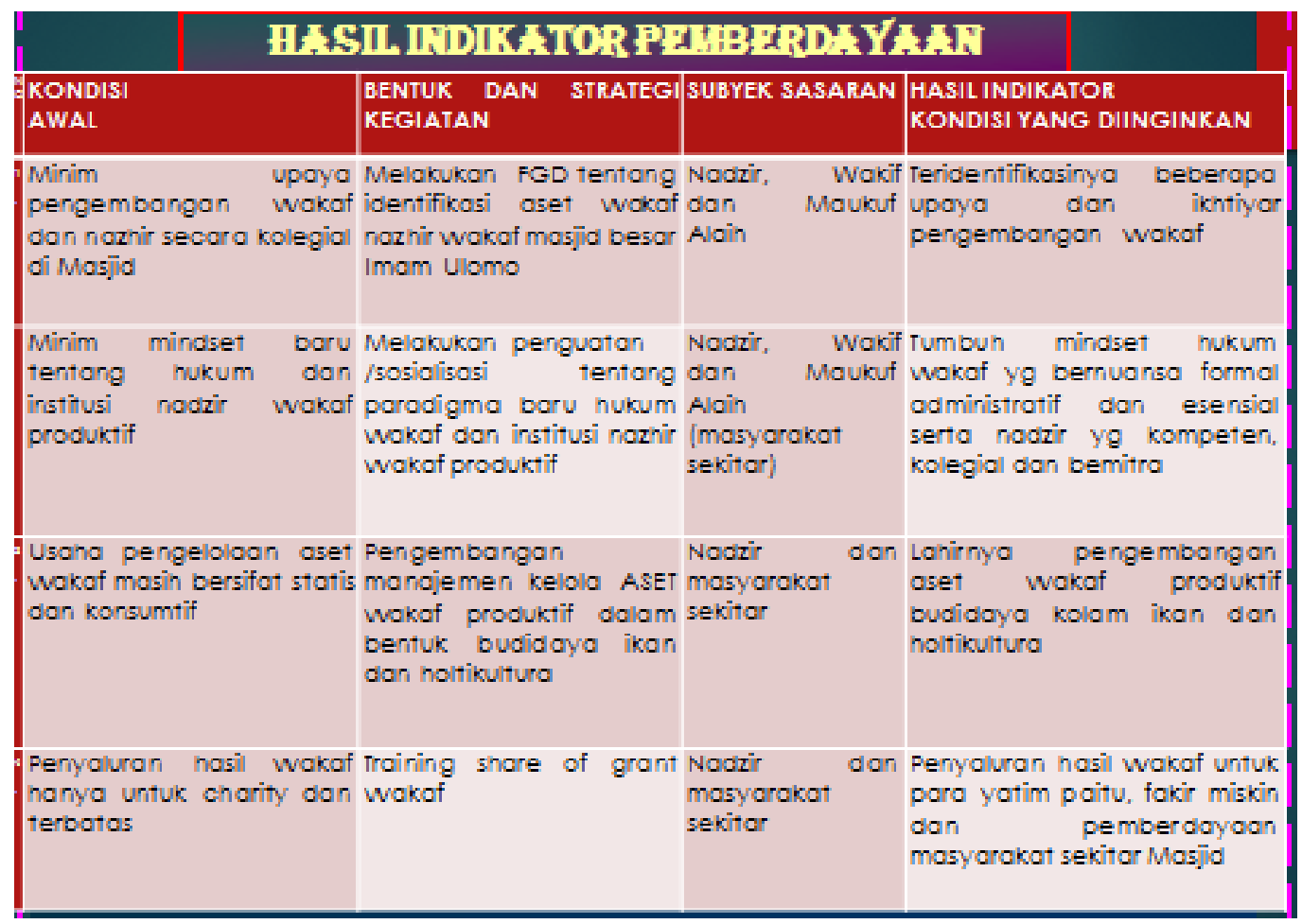

\section{Gambar Tabel Indikator Hasil Pemberdayaan}

Untuk kegiatan sosialisasi dan pelatihan, telah terlaksana dengan baik melalui kegiatan sosialisasi paradigma tata kelola wakaf produktif dan sosialisasi penguatan kelembagaan nadzir wakaf. Kegiatan ini terlaksana sesuai target, sehingga midset jamaah masjid tentang wakaf produktif semakin baik. Dengan terlaksananya kegiatan sosialisasi sesuai target maka terwujudnya Pemahaman Seputar Wakaf produktif, Tercipta Paradigma tata kelola Wakaf Produktif pada nadzir, serta terwujudnya kemitraan dalam pemberdayaan wakaf produktif. Sedangkan terkait pelatihan administrasi wakaf, terjadi peningkatan pemahaman dalam menyelesaikan prosedur administratif wakaf, mulai dari ikrar wakaf di KUA sampai sertifikasi wakaf di BPN. 


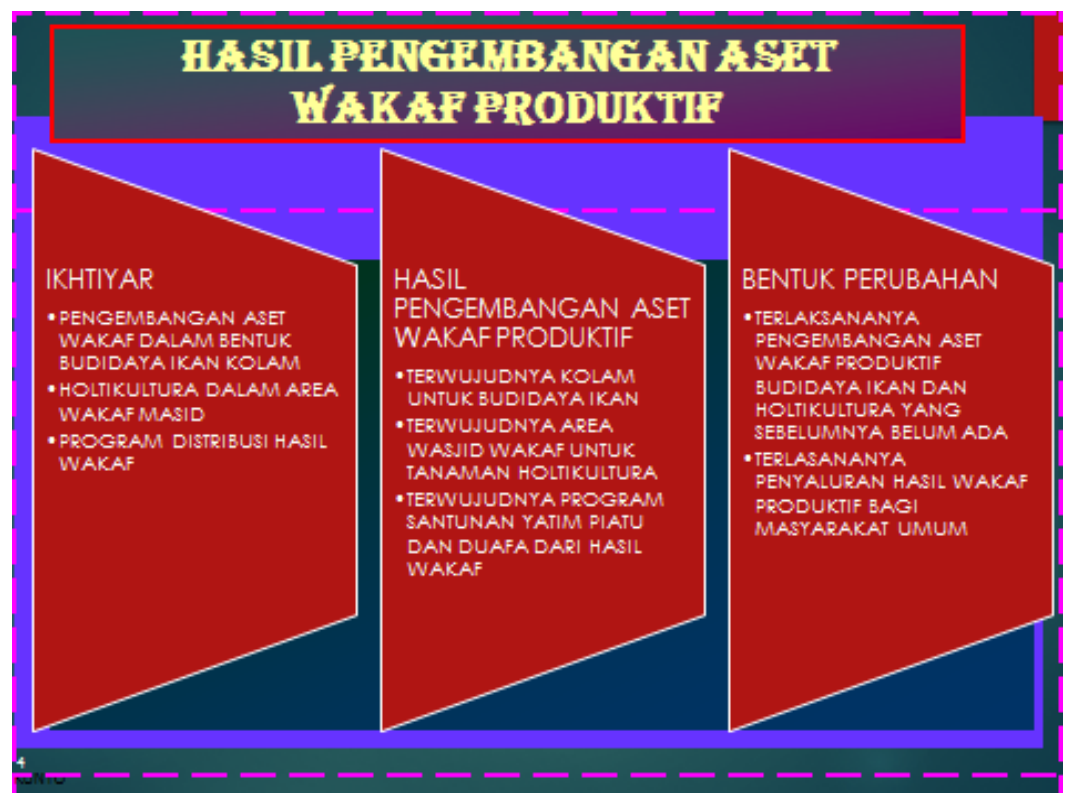

Sementara itu, untuk pelatihan penguatan kelembagaan nadzir dan peningkatan produktifitas aset wakaf, maka terwujudlah kolam ikan dan insentif budidaya ikan.

Adapun impikasi jangka panjang yang diharapkan dari telah terlaksananya kegiatan ini adalah semakin baiknya tata kelola wakaf produktif dan kelembagaan nadzir sehingga pengembangan aset wakaf secara produktif berdampak pada berkembangnya ekonomi umat.

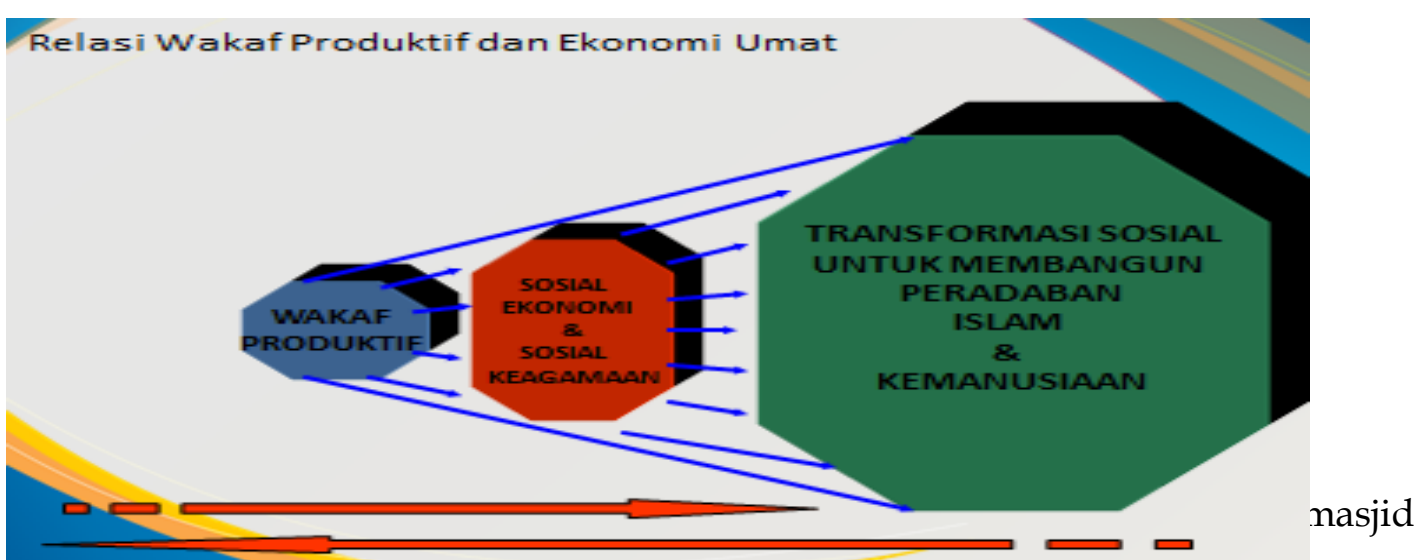

besar Imam Ulomo Sampung harus diberdayakan agar masjid sebagai lembaga Sosial Keagamaan juga merambah pada lembaga Sosial Ekonomi. Selain itu, penguatan jaringan dan kemitraan dengan berbagai stakeholders, mulai dari KUA, pemerintah desa, BWI, dan BPN harus terus dibangun semakin sinergis.

\section{F. Simpulan}


Berdasarkan kajian pengabdian Masjid Wakaf dan Transformasi Sosial Umat; Pemberdayaan Wakaf Berbasis Masjid Dari Sosial Keagamaan Menuju Sosial Ekonomi di Masjid Besar Imam Ulomo, Sampung Ponorogo, diatas, dapat disimpulkan: Pertama, terlaksana dengan baik melalui kegiatan sosialisasi paradigma tata kelola wakaf produktif. Kedua, pelatihan penguatan kelembagaan nadzir wakaf. Kegiatan ini sangat bermanfaat bagi pengembangan dan peningkatan tata kelola wakaf produktif di masyarakat, khususnya kelembagaan masjid wakaf.

Adapun rekomendasi dari kegiatan pengabdian Masjid Wakaf dan Transformasi Sosial Umat; Pemberdayaan Wakaf Berbasis Masjid Dari Sosial Keagamaan Menuju Sosial Ekonomi di Masjid Besar Imam Ulomo, Sampung Ponorogo Jawa Timur, yaitu: harus terus diprogramkan secara berkelanjutan. Hal ini agar terjaga mutu pengabdian dan dalam rangka mewujudkan transformasi sosial umat melalui aset wakaf produktif di kabupaten Ponorogo, khususnya dan Indonesia pada umumnya.

\section{DAFTAR PUSTAKA}

A. L. Chaney, and T. L. Burke. Teaching Oral Communication in Grades K-8. Boston: Allyn \& Bacon, 1998.

Abdurrahman Ibn Ibrahim, and Al-dilalah-Fauzan. Idhaat Ta'lim Al-Lughah Al-Arabiyah Li-Ghairi an-Nathiqiina Biha. Riyadh: T.P., 2011.

Acep Hermawan. Metodologi Pembelajaran Bahasa Arab. 1st ed. Bandung: PT. Remaja Rosdakarya, 2011.

Ahmad Fuad Effendy. Metodologi Pengajaran Bahasa Arab. Malang: Misykat, 2005.

Ali Ahmad Madkur, and et. al. Al Marja, Fi Manahij Ta'lim Al-Lughah Al-Arabiyah Li AnNatiqina Bi Lughat Hkhra. 1st ed. Cairo: Kairom Daar al-Fikr, 2010.

Chaplin, J.P. Kamus Lengkap Psikologi, Terjemahan K. Kartono. Jakarta: PT Raja Grafindo Persada, 2000.

Cooper, Paul, and Paul McIntyre. Effective Teaching and Learning. Philadelphia: Open University Press, 1996.

Covey, S. R. The 7 Habits of Highly Effective People. Jakarta: Binarupa Aksara, 1997.

Dimyati, Mudjiono. Proses Belajar Mengajar. Jakarta: Bumi Aksara, 2006. 
Henry Guntur Tarigan. Metodologi Pembelajaran Bahasa I. Bandung: Penerbit Angkasa, 1991.

Henson, K.T., and B.E. Eller. Educational Psychology for Effective Teaching. Belmont: Wadsworth Publishing Company, 1999.

H.G. Widdowson. Teaching Language as Communication. London: Oxford University Press, 2008.

Ibrahim, Bafadal. Dasar-Dasar Manajemen Dan Supervisi Taman Kanak-Kanak. Jakarta: PT Bumi Aksara, 2005.

Kunandar. Guru Profesional Implementasi Kurikulum Tingkat Satuan Pendidikan (KTSP) Dan Persiapan Menghadapi Sertifikasi Guru. Jakarta: PT Raja Grafindo Persada, 2007.

Loghran, J. John. Developing Reflective Practice. London: Falmer Press, 2005.

Majid, Abdul. Perencanaan Pembelajaran: Mengembangkan Standar Kompetensi Guru. Bandung: Remaja Rosdakarya, 2011.

Mohammad Abdul Qadir Ahmad. Turuq Ta'lim Al-Lughah Al- Arabiyaj. 5th ed. Cairo: Maktabah an-Nahdhah al-Mishriyyah, 1986.

Muhammad Ali al-Khauli. Al Hayah Ma'a Lughaten: Atsunaiyyah Al-Lughawiyyah. Mamlakah al Arabiyah Su'udiyah: Jami' al Huquq Mahfudzah 1 al Muallif, 1988.

Mulyasa, E. Standar Kompetensi Dan Sertifikasi Guru. Bandung: Rosda Karya, 2008.

Phillips, J.J. Handbook of Training Evaluation and Measurement Methods. Houson: Publishing Company, 1991.

Powell, William, and Ochan Kusuma. How to Teach Now. Virginia: ASDC, 2011.

Stephen D. Krashen. Principles and Practice in Second Language Acquisition. California: Pergamon Press Inc., 2009.

- - - Second Language Acquisition and Second Language Learning. New York: University of Southern California, 2002.

Winkel. Psikologi Pengajaran. Jakarta: Grasindo, 1996. 